\title{
Hrvatski jezik u Bosni i Hercegovini - život na rubu (egzistencija i perspektive)
}

Sažetak: U radu će se razmotriti položaj hrvatskoga jezika u Bosni i Hercegovini i pokušati odgovoriti na pitanje trebaju li se Hrvati u toj državi služiti hrvatskim standardnim jezikom kakav je normiran u Zagrebu ili trebaju inzistirati na svojim posebnostima koje su rezultat društvenih i političkih utjecaja i stoljetne odvojenosti od matice. Kako se postaviti prema brojnim orijentalizmima koji su sastavni dio leksika bosansko-hercegovačkih Hrvata, kao što su npr. germanizmi, talijanizmi ili hungarizmi sastavni dio leksika nekih drugih hrvatskih dijelova?! Postoji struja koja smatra da hrvatski jezik u BiH treba i mora biti poseban nekim svojim rješenjima prema hrvatskomu jeziku kakav je normiran u Zagrebu. Njihovo je gledište da je hrvatski jezik, kao i sam hrvatski narod u BiH, sustavno zanemarivan od središnjice i tek prigodno iskorištavan za dnevno-političke obračune. Nasuprot njima stoji jedino sveučilište na hrvatskom jeziku u BiH (Sveučilište u Mostaru) koje prati zadane jezične smjernice iz Hrvatske pozivajući se na jedinstvenost hrvatskoga naroda i jezika kojim se služe svi Hrvati, bez obzira na državu stanovanja. Tko je u pravu i može li samo netko biti u pravu ili je rješenje za bosansko-hercegovačke Hrvate u nekom trećem, srednjem putu, pokušat će se naznačiti u radu.

Ključne riječi: hrvatski jezik, Bosna i Hercegovina, normiranje, periferija, egzistencija, perspektiva

\section{Uvod}

Bosna i Hercegovina postala je spletom povijesnih okolnosti sjecište raznih, često suprotstavljenih, kultura i to je obilježilo njezine stanovnike. Prva i osnovna prepreka koja je priječila nacionalno jedinstvo u vrijeme pojave nacija u Europi bila je vjerska razjedinjenost naroda koji su stoljećima bili pod osmanskom upravom. Dolazak Austro-Ugarske, 
a potom i južnoslavenske zajednice nije mnogo pridonio (narodnomu) jedinstvu jer su se hrvatska i srpska nacija već bile razvile, dok je kod bosansko-hercegovačkih muslimana postojao otklon i distanciranje prema kršćanskim susjedima, iako su i jedna i druga nacija nastojale pridobiti muslimansko stanovništvo na svoju stranu. U takvom vjerskom i političkom odnosu, ni književni ni jezični odnos među stanovništvom nikada nije pokazivao jedinstvo, nego se striktno znalo što komu pripada. Tako su vjerska i jezična obilježja postala razlikovne odrednice nacionalnih zajednica koje će se formirati na prostoru današnje Bosne i Hercegovine pa su npr. katolicima iz BiH svjetonazorski i kulturno bili puno bliži katolici iz Hrvatske nego druge dvije vjerske zajednice s kojima su živjeli u ,zajedničkoj“ državi. Na tom jedinstvenom duhovnom području stoga ne čudi da su im katolički kajkavci i čakavci postali bliži od štokavaca drugih vjera s kojima su dijelili državne granice. Prožimanjem tijekom stoljeća naizgled različitih jezičnih ${ }^{1}$ polazišta nicala je jedinstvena jezična zajednica koja se formirala u istom civilizacijskom krugu i koja je imala svoj isti jezični kôd, odnosno Hrvati su postali, kako to definira Bloomfield „A group of people who use the same system of speech-signals“"2.

Tek se u drugoj polovici 20. stoljeća, nakon što su u socijalističkoj Jugoslaviji došle do izražaja sve hrvatsko-srpske različitosti, nastoji u Bosni i Hercegovini umjetno stvoriti privid bratstva i jedinstva i neovisnosti o drugim bivšim socijalističkim republikama unutar SFRJ-a. To se posebice pokušalo preslikati na jezičnom planu pa se nastojala voditi jedinstvena jezična politika koja je, barem teoretski, trebala obuhvatiti sve tri narodnosne skupine u $\mathrm{BiH}$, s otklonom naspram SR Hrvatske i SR Srbije. Ipak, već krajem osamdesetih i početkom devedesetih došlo je do kraha takve jezične politike kada se sva tri naroda odlučuju na odmak od dotadašnjih pogleda. Srbi su se u početku okrenuli srbijanskoj jezičnoj politici pa su čak bili uveli i ekavicu koja se ipak pokazala „neprirodnom“ i samomu srpskomu stanovništvu u BiH pa se ubrzo odustalo od takvih pokušaja, ali se slična jezična politika nastavila provoditi i graditi na ijekavskom izgovoru. Bošnjaci su na dotadašnjoj socijalističkoj jezičnoj politici preuzetoj iz $\mathrm{SR} \mathrm{BiH}$ nastojali izgraditi vlastiti standard u koji su ukomponirali velik broj orijentalizama, a neki otvoreno tvrde da je upravo taj njihov jezik legitimni nastavljač jezične

\footnotetext{
${ }^{1}$ Vidjeti npr. Ljetopis Nikole Lašvanina koji dio svoje građe preuzima iz Vitezovićeva djela Kronika aliti szpomen vszega szvieta vikov. Ignacije Gavran, „Uvod,“ u Nikola Lašvanin. Ljetopis, ur. Ignacije Gavran (Sarajevo-Zagreb: Synopsis, 2003) 14-16.

${ }^{2}$ Leonard Bloomfield, Language (London: George Allen \& Unwin Ltd., 1973), 29.
} 
prakse iz doba socijalističke $\mathrm{BiH} .{ }^{3}$ Bosansko-hercegovački su Hrvati prihvatili jezičnu politiku iz Republike Hrvatske, vrlo malo ili gotovo nimalo ne sudjelujući u njezinoj provedbi i upravo će ta „slijepa poslušnost" proizvesti najveće otpore u jednom dijelu hrvatske kulturne zajednice o čem će biti više riječi u nastavku rada.

\section{Službeni jezik koji nije u skladu s Ustavom}

Prema De Saussureovim postavkama da ,jezik ima individualnu i društvenu stranu i nemoguće je pojmiti jednu bez druge ${ }^{64}$, odnosno da ,jezik postoji samo zahvaljujući svojevrsnom dogovoru sklopljenom između pripadnika zajednice" ${ }^{\text {s5 }}$ možemo promatrati i pitanje hrvatskoga jezika u Bosni i Hercegovini, odnosno prijepore koji su se javili u jednom (manjem) dijelu hrvatske kulturne zajednice u BiH. Naime, hrvatski je jezik jedan od triju službenih jezika Bosne i Hercegovine i kao takvom bi mu trebala biti zajamčena sva prava koja proizlaze iz te činjenice. Ipak, jezična situacija u Bosni i Hercegovini čini se da slijedi onu političku pa su prava bilo kojega naroda u BiH zajamčena samo $\mathrm{u}$ većinski naseljenom području pojedinoga naroda, dok se u drugim dijelovima sustavno zanemaruju ili pak krše. Osobito se u posljednje vrijeme ističe „činjenica“ da inzistiranje na jezičnoj posebnosti doprinosi raslojavanju bosansko-hercegovačkoga društva, nadajući se da će se tako nekim birokratskim potezom prebrisati nacionalne posebnosti u BiH. Zabrinjava i podatak da je Ustavni sud $\mathrm{BiH}$ još 1998. stavio „,izvan zakona“6 termine županija i bošnjački jezik čime se svrstao na stranu zagovornika da u $\mathrm{BiH}$ ne postoje različiti jezici koji bi eventualno mogli imati svoje nazivlje jer takvi „termini“ ne postoje u Ustavu. ${ }^{7}$

\footnotetext{
${ }^{3}$ Ibrahim Čedić, „Bosanskohercegovački standardnojezički izraz - bosanski jezik,“ u Bošnjački pogledi na odnose između bosanskog, hrvatskog i srpskog jezika, ur. B. Tošović i A. Wonisch (Graz - Sarajevo: Institut für Slawistik der Karl-Franzens-Universität Graz - Institut za jezik, 2009), 42.

${ }^{4}$ Ferdinand de Saussure, Tečaj opće lingvistike (Zagreb: ArTresor naklada - Institut za hrvatski jezik i jezikoslovlje, 2000), 54.

${ }^{5}$ Saussure, Tečaj opće lingvistike, 60.

${ }^{6}$ Presuda Ustavnoga suda Federacije BiH, broj U-7/98, 1998., pristupljeno 22. lipnja 2019., http://www.ustavnisudfbih.ba/bs/open_page_nw.php?l=bs\&pid=178.

${ }^{7}$ U presudi Ustavnoga suda stoji: „Utvrđuje se da upotreba naziva ,županija“ u čl. 1-18, 21, 26, 27, 29, 30, 36, 38, 42, 43, 45, 47, 49, 57, 71, 73, 78, 82. i 84. Ustava Zapadnohercegovačkog kantona nije u skladu s Ustavom Federacije Bosne i Hercegovine.“, dok se u obrazloženju navodi sljedeće: „Članom 11. Ustava Kantona nedosljedno je preuzet član V. 3. Ustava Federacije $\mathrm{BiH}$, tako da je dobio drugi smisao i da je član 30. Ustava Kantona koji uređuje
} 
Službeni Ustav Federacije BiH koji je tada bio u uporabi, u članku 6. navodi sljedeće: „Službeni jezici Federacije su bosanski jezik i hrvatski jezik. Službeno pismo je latinica." ${ }^{\text {(8 }}$ pa tu naizgled nema nikakvih dvojbi. Ali, kako je moguće da i u hrvatskoj inačici dokumenta, iako većina hrvatskih jezikoslovaca jezik Bošnjaka naziva bošnjačkim, a ne bosanskim, ${ }^{9}$ piše upravo to? Odgovor je još davno dao sudac Ustavnoga suda Federacije BiH Mirko Bošković, koji je donio izdvojeno mišljenje o ustavnosti tih naziva u kojem jasno navodi da ,sa sigurnošću se može zaključiti da je Ustavotvorna skupština usvojila Ustav Federacije 30. ožujka 1994. godine, na hrvatskom jeziku u čijem je članku 6. stavak 1. Ustava Federacije regulirano da su službeni jezici Federacije bošnjački jezik i hrvatski jezik ${ }^{\text {"10 }}$, a da je naknadnom intervencijom tajnika Komisije za ustavna pitanja Ustavotvorne skupštine napravljena zamjena naziva koja nije u skladu sa zakonom jer tajnik ,nije ovlaštena osoba da daje naloge za ispravke Ustava Federacije Bosne i Hercegovine“"11.

Kad se tim podatcima prilože i podatci o pokušajima razjedinjavanja hrvatskoga jezika unutar samoga hrvatskoga korpusa u Bosni i Hercegovini, onda se s pravom može postaviti pitanje kojim smjerom bi trebao ići daljnji razvoj hrvatskoga jezika u BiH.

da Kanton ima ,župana‘ suprotan članu V. 3. 8. (1) Ustava FBiH kojim je uređeno da svaki kanton ima ,predsjednika', da Ustav Federacije BiH ne poznaje ni termin ,županija“ nego termin ,kanton', (čl. I. 2, V. 4. stav 2.) i da upotreba naziva ,županija' u čl. 1-18, 21, 26, 27, $29,30,36,38,42,43,45,46,47,49,57,71,73,78,82$. i 84. Ustava Kantona nije u skladu sa Ustavom Federacije Bosne i Hercegovine.“ (http://www.ustavnisudfbih.ba/bs/open_page_ nw.php?1=bs\&pid=178).

${ }^{8}$ Ustav Federacije Bosne i Hercegovine, 1994., pristupljeno 31. srpnja 2020., http://www. fbihvlada.gov.ba/hrvatski/federacija/ustav_hr_stari.htm. Amandmanom XXIX pridodan je i srpski jezik i ćirilica kako bi se ravnopravnost svih naroda zajamčila na cijelom teritoriju BiH (Ustav Federacije Bosne i Hercegovine s amandmanima XXVII-LIV (Wolfgang Petrisch) od 28. 4. 2002., pristupljeno 31. srpnja 2020., http://predstavnickidom-pfbih.gov.ba/ upload/file/ustav/ustav_precisceni_tekst.pdf).

9 Autor smatra da svaki narod ima pravo imenovati svoj jezik onako kako želi pa tako i Bošnjaci svoj, ali isto tako to ne obvezuje druge narode da taj jezik tako nazivaju, odnosno i oni imaju pravo imenovati taj jezik svojim nazivom, a da se odmah u tom činu ne traže negiranja postojanja pojedinoga naroda i jezika.

${ }^{10}$ Mirko Bošković, Odvojeno mišljenje suca mr Mirka Boškovića u predmetu U-12/97 (1998), pristupljeno 18. rujna 2019., http://www.ustavnisudfbih.ba/hr/open_page_ nw.php?l=hr\&pid=151.

${ }^{11}$ Bošković, Odvojeno mišljenje. O tom je slučaju s istim zaključcima u magazinu Dani pisao i Radoslav Dodig, tadašnji član Ustavotvorne skupštine BiH i Komisije za utvrđivanje istovjetnosti tekstova na dvama jezicima (usp. Radoslav Dodig, „Bošnjački ili bosanski,“ Dani, 132 (1999), pristupljeno 29. srpnja 2020., http://hamdijadobruna.com/fstab/jezik6. html\#bl. 


\section{Kakav treba biti hrvatski jezik u BiH?}

Da bismo odgovorili na gore postavljeno pitanje, ponovno ćemo se malo vratiti u prošlost. Problem s razvojem hrvatskoga standardnoga jezika poznat je odavno, a to je prvenstveno bila rascjepkanost hrvatskoga teritorija i njegova podijeljenost između raznoraznih država koja je otežavala njegovu standardizaciju. I dok su se hrvatske povijesne zemlje uspjele nekako ujediniti, područja Bosne i Hercegovine naseljena većinskim hrvatskim stanovništvom ostala su izvan tih državnih granica, ali uvijek u kulturnoj povezanosti s ostatkom matice. Budući da su Hrvati predstavljali manjinu unutar ukupnoga stanovništva BiH bilo im je i teže, ovisno o vremenima, zadržati pojedine jezične posebnosti pa je tako, što prirodno, što pod prisilom došlo do jezičnoga miješanja s drugim narodima u $\mathrm{BiH}$.

Ipak, utjecaj Bosne i Hercegovine, kao i Hrvata iz BiH na razvitak hrvatskoga jezika nije zanemariv. Zna se da su bosansko-hercegovački franjevci položajem svoje provincije i svojim djelovanjem unutar te provincije odigrali odlučujuću ulogu u širenju pismenosti te u kulturnom povezivanju hrvatskoga juga i sjevera. Dalibor Brozović upravo ističe tu, prečesto zaboravljanu, važnost i ulogu provincije Bosne Srebrene na oblikovanje hrvatskoga jezičnoga izričaja:

$\mathrm{Na}$ štokavskom i donekle južnočakavskom području glavni su nosioci sličnih procesa bili franjevci provincije Bosne Srebrene, i to je činjenica kojoj se važnost nikada ne može dovoljno naglasiti. Franjevci su jadranske jezične tekovine iz Dubrovnika i mletačke Dalmacije usvojili i prenijeli u Slavoniju i u hrvatske naseobine u Ugarskoj. Bitna je činjenica da su se svi štokavski Hrvati nalazili u krugu djelovanja Bosne Srebrene, da je ona čvrsto povezivala Dalmaciju i Slavoniju i da njezin utjecaj nije prestajao nakon postupnoga otpadanja pojedinih krajeva ispod njezine jurisdikcije. ${ }^{12}$

Ulogu bosansko-hercegovačkih franjevaca ne samo u standardizaciji hrvatskoga jezika, nego i drugih jezika nastalih na štokavskoj osnovi naglašava i Ivo Pranjkovićn 13 što jasno govori da hrvatskoga jezika, kakva

\footnotetext{
${ }^{12}$ Dalibor Brozović, „Uloga bosanskohercegovačkih franjevaca u formiranju jezika hrvatske književnosti i kulture - od Divkovića do fra Grge Martića,“ Jezik: časopis za kulturu hrvatskoga književnog jezika, god. 20, br. 2 (1972): 42.

${ }^{13}$ Usp. Ivo Pranjković, Franjevačko spisateljstvo na hrvatskome jeziku (Zagreb: Hrvatska sveučilišna naklada, 2008), 27.
} 
danas poznajemo, ne bi bilo bez njihova samoprijegornoga rada. Naravno da se promjenom društveno-političkih okolnosti smanjila i franjevačka uloga i utjecaj na hrvatski jezik jer su se tijekovi standardizacije prenijeli na druga područja, ali su se i u bližoj prošlosti osluškivale odluke donesene u $\mathrm{BiH}$ (ovaj put odluke službenih vlasti) koje su onda ostavile velike posljedice na završnu fazu standardizacije hrvatskoga jezika. Tako Antun Radić naglašava da mu je Ivan Broz, govoreći o razlozima uvođenja fonološkoga pravopisa, kao ključni čimbenik naveo Bosnu i Hercegovinu jer da bi inače Hrvatska te krajeve zauvijek izgubila. ${ }^{14}$ O situaciji u Bosni i Hercegovini i utjecaju koji je imala tih godina na jezičnu situaciju u Hrvatskoj govori i Stjepan Ivšić koji prenosi Klaićeve riječi o razlozima uvođenja novih padežnih oblika i fonološkoga pravopisa u izdanjima Matice hrvatske u kojima je apostrofirao BiH ,jer je vlada ondje učinila jedno i drugo" ${ }^{\text {"15 }}$. U svojim je prisjećanjima Bosnu i Hercegovinu spomenuo i sam Tomo Maretić, aktivni sudionik tih zbivanja, opisujući ključne godine dovršetka jezične standardizacije: „Od argumenata što ih je Kršnjavi banu naveo, predlažeći mu onu naredbu na potpis, najviše je delovalo to što i fonetiku i nove padeže upotrebljava Bosna i Hercegovina i grad Dubrovnik" ${ }^{\text {"16 }}$. Tako je BiH, bilo izravnim djelovanjem svojih franjevaca, bilo neposrednim utjecajem političkih čimbenika, odigrala ogromnu ulogu u samoj Hrvatskoj. Već sam taj put kojim se kretao razvoj i standardizacija hrvatskoga jezika, a koji nisu prošla ostala dva jezika u BiH, pokazuje da je hrvatski jezik samosvojan i nedjeljiv bez obzira na nekakve republičke, entitetske ili državne granice unutar kojih živi hrvatski narod.

Kad se je moglo očekivati da će se jezična situacija smiriti i da će se svi Hrvati „ujediniti““ u istom jezičnom izričaju, došlo je do raspada Austro-Ugarske Monarhije i ulaska u novu državnu zajednicu koja je svojom jezičnom politikom prisiljavala i samu Hrvatsku na promjenu jezične politike (Pravopisno uputstvo 1929.), a u BiH je krenula s otvorenim posrbljivanjem, ${ }^{17}$ koje će se nastaviti i nakon propasti prve Jugo-

\footnotetext{
${ }^{14}$ Usp. Antun Radić, „Hrvatski književni jezik,“ Glas Matice Hrvatske, god. II, br. 1-2 (1907): 4.

${ }^{15}$ Stjepan Ivšić, „Etimologija i fonetika u našem pravopisu,“ Hrvatski jezik, god. 1, br. 1 (1938): 13.

${ }^{16}$ Tomo Maretić, ,Jedna značajna četrdesetogodišnjica - Kako je došlo do uvođenja fonetskog pravopisa u Hrvatskoj i Slavoniji 1892,“ Pravda, god. XXVIII, br. 6-9 (1932): 19.

${ }^{17}$ Da je nakon dolaska Kraljevine SHS u Bosni i Hercegovini planski provođena srpska politika u BiH kojom se nastojalo potisnuti hrvatsko nazivlje potvrđuje Papić, usp. Mitar Papić, Školstvo u Bosni i Hercegovini za vrijeme austro-ugarske okupacije (1878 - 1918) (Sarajevo: Veselin Masleša, 1972), 169-170.
} 
slavije. Situacija je posebice postala teška nakon Drugoga svjetskoga rata, kada se u BiH proganjaju hrvatske riječi i proglašavaju „ustaškim“ te se nastoji nametnuti srpski jezični izričaj. Ipak, zahvaljujući književnicima i crkvenim tiskovinama hrvatski jezik uspio je zadržati svoje karakteristike i svoju vitalnost u suodnosu s drugim jezicima.

Pokušajem stvaranja jedinstvenoga bosanskohercegovačkoga standardnojezičnoga supstrata koji je kao „treća varijanta“ trebao u BiH sačuvati već tada urušeni koncept srpskohrvatskoga/hrvatskosrpskoga jezika, nastojalo se u biti u BiH nametnuti srpski jezik ijekavskoga izgovora svim stanovnicima. Tako se pod okriljem samosvojnosti i ,trećega puta" u Bosni i Hercegovini želio normirati jezični sustav koji je često bio u suprotnosti s narodnim govorima svih triju naroda ili barem $\mathrm{u}$ suprotnosti s govorima većine naroda u BiH. ${ }^{18}$ Bez obzira na sustavnu političku podršku republičkih vlasti, taj se „bosanskohercegovački standardnojezički izraz" raspadom bivše države i sam raspao. Bila je to umjetna tvorevina s kojom su se na koncu uspjeli identificirati ponajviše tadašnji Muslimani koji su napokon dobili pravo na predstavljanje svojega kulturnoga naslijeđa pa su prigrlili taj jezični konstrukt kao novu mogućnost i nešto drukčije od hrvatskoga i srpskoga koji im se do tada nudio. I danas postoje tendencije da se taj konstrukt oživi pa mu se pripisuje ono što nikada nije bio, ravnopravan jezični idiom svih stanovnika $\mathrm{BiH}$. Posebice zabrinjava činjenica da se na primjerima mjesnih govora nastoji dokazati „sličnost“ jezika miješajući to s načelima standardnosti. Ta je tendencija prisutna kod pojedinih bošnjačkih jezikoslovaca koji, poput Ismaila Palića, idu još i dalje pa tvrde da je ,potpuno jasno da je Bosna i Hercegovina, jezički gledano, jedna zasebna cjelina“119, ili pak poput Mevlide Karadža koja naglašava da „nema nikakvog lingvističkog opravdanja za napuštanje zajedničkog standarda“20, jer polaze od činjenice da svi konstitutivni narodi u BiH imaju standard s osnovicom na (i)jekavskoj štokavštini. Jasno je što se krije iza takvih ocjena i koji bi jezik trebao biti dominantan u $\mathrm{BiH}$ kad se pogledaju izjave pojedinih

\footnotetext{
${ }^{18}$ Usp. Marija Musa, Hrvatski jezik u Bosni i Hercegovini u javnoj komunikaciji od 1945. do danas (Mostar: Školska naklada, 2018), 62-64.

${ }^{19}$ Ismail Palić, „Mogućnosti funkcioniranja triju standardnih jezika (bosanskoga, hrvatskoga i srpskoga) u Bosni i Hercegovini,“ u Bošnjački pogledi na odnose između bosanskog, hrvatskog i srpskog jezika, ur. B. Tošović i A. Wonisch (Graz - Sarajevo: Institut für Slawistik der Karl-Franzens-Universität Graz - Institut za jezik, 2009), 81.

${ }^{20}$ Mevlida Karadža, „Sociolingvistički aspekti jezičke situacije u Bosni i Hercegovini,“ u Bošnjački pogledi na odnose između bosanskog, hrvatskog i srpskog jezika, ur. B. Tošović i A. Wonisch (Graz - Sarajevo: Institut für Slawistik der Karl-Franzens-Universität Graz - Institut za jezik, 2009), 73.
} 
bošnjačkih političara, ali i kulturnih radnika pa i jezikoslovaca da su srpska i hrvatska nacija „,uvezene“ u BiH, a samim time i njihovi jezici i da je jedini ,ispravan“ put povratak u bosansko ,jato“. ${ }^{21}$

Zabrinjava što se takvim mišljenjima priklanjaju i pojedini hrvatski kulturni radnici koji, iako u manjini u vlastitom narodu, potpomognuti medijima većinskoga naroda vješto plasiraju svoje teze o nametanju umjetne zagrebačke jezične varijante Hrvatima u $\mathrm{BiH}$, a ne zapitaju se pod kakvim su i čijim nametanjem bili do tada Hrvati u BiH. Tu osobito prednjači Ivan Lovrenović koji je 2012. objavio Promemoriju $o$ (hrvatskoj) jezičnoj politici u Bosni i Hercegovini ${ }^{22}$ u kojoj upozorava na, po njemu, pogubnu pojavu u hrvatskom jeziku u BiH. Iako u svojem tekstu donosi važne stvari o kojim bi trebalo konstantno promišljati, ${ }^{23}$ nažalost on već u početku polazi od jednoga zajedničkoga jezika i sve daljnje zaključke izvodi iz te perspektive. Govoreći o inzistiranju na

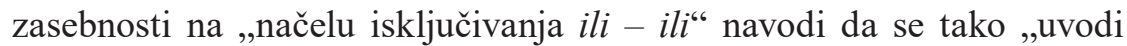
grubi politički diktat nad živom stvarnošću jezika, kao i nad drugim aspektima sociokulturnoga ambijenta“, ali i sam upada u istu zamku zanemarivanja ,žive stvarnosti““ i „sociokulturnoga ambijenta“ jer ne prihvaća da su se stvari promijenile. A da bi se, kako ju on naziva, „sačuvala funkcionalna jedinstvenost jezičnoga prostora“ upravo treba prihvatiti novonastalo činjenično stanje da tri različita naroda, ma koliko bliski bili, žele (to je ključno!) imati različite (samosvojne) jezike u odnosu na druge narode $\mathrm{s}$ kojima žive. I to ne narušava unutarnje bosansko-hercegovačke odnose, nego, naprotiv, nakon toliko vremena suživota u zajedničkim (tuđim) državama pruža mogućnost istinskoga života svih stanovnika Bosne i Hercegovine na ravnopravnim i jednakim osnovama (u svojoj državi). Sve dok se u ime nečega višega i zajedničkoga budu potiskivale želje bilo kojega naroda u Bosni i Hercegovini, nastajat će daljnji nesporazumi. Lovrenović nudi tri moguća puta kojima bi mogao (trebao) krenuti hrvatski jezik u $\mathrm{BiH}$, ali već kod prvoga ponovno upada u zamku vlastitih predodžaba pa naglašava da je ako ,se inercijski nastavi dosadašnjim putem, nekritički i nekreativno usvajajući normativna rješenja koja dolaze iz Zagreba“ put unaprijed poznat, a to je „sve veće produbljivanje jaza između

\footnotetext{
${ }^{21}$ Usp. Senahid Halilović, „Jezička stvarnost u Bosni i Hercegovini,“ Socjolingwistyka, XXVIII (2014): 133.

${ }^{22}$ Ivan Lovrenović, Promemorija o (hrvatskoj) jezičnoj politici u Bosni i Hercegovini (2012), pristupljeno 5. travnja 2019., https://www.6yka.com/novosti/promemorija-o-hrvatskoj-jezicnoj-politici-u-bosni-i-hercegovini.

${ }^{23}$ Osobito kad je riječ o „deficitu autokritičnosti“ i prebacivanju odgovornosti na druge.
} 
materinskoga idioma i nacionalnog standarda“. Tu kao da je zaboravio da nijedan „materinski idiom“, ma kako čist i dobar bio, ne čini sam po sebi standardni jezik, odnosno svaki standardni jezik treba do neke mjere učiti i usvajati. Na kraju krajeva, može se postaviti pitanje zašto bi baš taj „materinski idiom“ hrvatskih govora bio u drukčijoj poziciji prema drugim ,materinskim idiomima“, zasigurno ne samo zato što mu je u podlozi štokavsko narječje?! Druga opcija koju nudi „da se vlastitim snagama poradi na specifičnoj, bosanskohercegovačkoj standardizaciji hrvatskoga jezika“" odvodi bosansko-hercegovačke Hrvate u poziciju „drugih“ Hrvata (a to već jesu u političkom smislu, bez obzira gledalo se na njih iz Zagreba ili iz Sarajeva) koji ne znaju kamo ustvari pripadaju. A tad im je najlakše elegantno ponuditi (nametnuti) neko treće rješenje, koje i sam Lovrenović nudi i naziva „civilizacijski optimalnim“, iako se odmah ograđuje ,jer za nju nema minimuma volje ni na hrvatskoj ni na bošnjačkoj ni na srpskoj strani““. Dakle, po njem, treba raditi na tom da se ,postigne dogovor o zajedničkoj bosanskohercegovačkoj standardizaciji, s konjunktivnom normom koja bi priznavala i izražavala sve nacionalno-jezične specifičnosti tamo gdje ih ima“. Time smo ponovno vraćeni u razdoblje jedinstvenoga bosanskohercegovačkoga standardnojezičnoga izraza koji, kao „mogućnost rješenja“ jezične situacije u BiH, nude i pojedini bošnjački jezikoslovci. ${ }^{24}$ Postavlja se pitanje zašto se misli da bi takav konstrukt zaživio sada, a nije uspio zaživjeti prije kad je bio potpomognut socijalističkim republičkim aparatom? Kada se navedenomu pridoda i pojava Deklaracije o zajedničkom jeziku ${ }^{25}$ skupine jezikoslovaca i kulturnih radnika koji na štokavskom govornom području vide jedan zajednički jezik, onda za područje BiH možemo uočiti dva plana: manji koji pod bosanskim imenom unutar granica $\mathrm{BiH}$ nastoji oživjeti jezik koji se pokušao normirati od 1970-ih godina i veći postjugoslavenski koji pod krinkom jezičnih sloboda i „ukidanja svih oblika jezične segregacije“26 u cijeloj regiji želi nametnuti širi jezični okvir koji bi dopustio „slobodu ,miješanja‘, uzajamnu otvorenost te prožimanje različitih oblika i izričaja zajedničkog jezika“'27, što je ne samo u suprotnosti sa svim ustavima novonastalih država, nego i u su-

\footnotetext{
${ }^{24}$ Usp. Karadža, „Sociolingvistički aspekti jezičke situacije u Bosni i Hercegovini,“ 73.

${ }_{25}$ Autor ni u kojem slučaju ne uskraćuje pravo bilo komu da slobodno iznosi svoje stavove i da „osjeća“ jezike koji su se razvili na južnoslavenskom području zajedničkima.

${ }^{26}$ „Deklaracija o zajedničkom jeziku“ (2017), PEN Centar BiH iz Sarajeva, Udruženje Krokodil iz Beograda, Centar za građansko obrazovanje (CGO) iz Podgorice, Udruga Kurs iz Splita, pristupljeno 10. siječnja 2020., http://jezicinacionalizmi.com/deklaracija/.

27 „Deklaracija o zajedničkom jeziku“ (2017).
} 
protnosti s definicijom standardnoga jezika koji mora biti jasno propisan i normiran.

Ipak, u jednom se možemo složiti s Lovrenovićem, a to je da je možda napokon sazrelo vrijeme da se „hrvatska obrazovna i kulturna politika u Bosni i Hercegovini emancipira i počne kreirati autonomno, vlastitom pameću i u najboljem skladu s vlastitim potrebama i interesima“. Na tom tragu je i hrvatski književnik Josip Mlakić koji naglašava „,ne može se hrvatski jezik zatvoriti u granice Republike Hrvatske. On je podjednako vlasništvo i nas Hrvata u $\mathrm{BiH}^{\text {“" }}{ }^{28}$ Upravo na tom temelju, da je hrvatski jezik vlasništvo i Hrvata u Bosni i Hercegovini, treba graditi budući razvitak hrvatskoga jezika.

Hrvatski su jezikoslovci još devedesetih godina 20. stoljeća jasno izrekli svoj sud o tim pokušajima razdvajanja hrvatskoga naroda i jezika na one u Hrvatskoj i na one u BiH. Još je Dalibor Brozović upozorio da su jednako neprihvatljivi ,pokušaji da se bošnjački jezik nametne bosanskohercegovačkim Hrvatima, bezuvjetno su neprihvatljive i eventualne tendencije da se ostvari nekakav autonomni bosanskohercegovački hrvatski standardni jezik“29, kao što je neprihvatljivo „i zagrebačko sektaštvo prema orijentalizmima kao tobožnjim srbizmima“"30. Tako ne stoje Lovrenovićeve primjedbe da se Hrvati iz Bosne i Hercegovine tre-

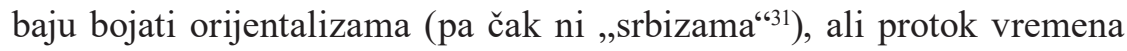
čini svoje i prirodnim ${ }^{32}$ odlaskom starijih generacija gubi se cijeli jedan jezični mikrokozmos koji, nažalost, mlađe generacije nikada ne će moći ni pojmiti, a kamoli rekonstruirati. To su činjenice.

I u novije vrijeme, kad se promišlja o hrvatskom jeziku u $\mathrm{BiH}$, prevladavaju pomirljivi, ali odlučni stavovi da je riječ o jednom narodu i jeziku, bez obzira na lokalne razlike u govorenom jeziku. Tako i Ranko Matasović uočava:

Što se tiče prevođenja s bošnjačkoga i srpskoga na hrvatski, rekao bih da to nije nešto što je potrebno provoditi u svakoj prigodi,

\footnotetext{
28 Josip Mlakić, „Hrvatski jezik je vlasništvo i nas Hrvata u BiH,“ Vijenac 373, 19. lipnja 2008. (2008) razgovor vodila Laura Mihaljević, pristupljeno 27. siječnja 2020., http://www. matica.hr/vijenac/373/hrvatski-jezik-je-vlasnistvo-i-nas-hrvata-u-bih-22218/.

29 Dalibor Brozović, „Odnos hrvatskoga i bosanskoga odnosno bošnjačkoga jezika,“ Jezik: časopis za kulturu hrvatskoga književnog jezika, god. 47, br. 1 (1999): 15.

${ }^{30}$ Brozović, „Odnos hrvatskoga i bosanskoga odnosno bošnjačkoga jezika,“ 15 .

${ }^{31}$ Navodnici su preuzeti od Lovrenovića.

32 Ovdje se ne spominje rat i protjeravanje gotovo svih Hrvata iz Bosanske Posavine i posljedice koje je to ostavilo na govor tih ljudi. Zasigurno nove generacije više nikada ne će poprimiti one jezične značajke koje su mogli poprimiti da su odrastali u ,prirodnoj“ sredini.
} 
već samo u pogledu tekstova koji imaju pravni značaj i u najformalnijim situacijama. Ali ne treba odustati od postojanja prava Hrvata da se s njima komunicira na njihovom vlastitom, hrvatskom standardnom jeziku: inače će u budućnosti o tome što je zajednički standardni jezik pretežito odlučivati većinski narod, ili dva većinska naroda $\mathrm{u} \mathrm{BiH} .{ }^{33}$

Kad se razmotre sve činjenice i sagleda današnja situacija s hrvatskim jezikom u Bosni i Hercegovini neminovno se nameću pojedini zaključci. Hrvatski jezikoslovci u BiH i/ili oni podrijetlom iz BiH trebaju se svakako aktivnije uključiti u proces normiranja hrvatskoga standardnoga jezika, a ne biti samo „konzumenti“ već ponuđenih rješenja. Prvo bi trebalo pokušati u $\mathrm{BiH}$, u osnovne i srednje škole, na sveučilišta i u medije uvesti jedan jezični standard. Možda bi trebalo pristupiti izradi maloga jezičnoga priručnika koji bi sadržavao pravopis, gramatiku i rječnik koji bi bio ,izrađen“ na Filozofskom fakultetu u Mostaru i koji bi uzeo u obzir i posebnosti Hrvata u BiH. Bosansko-hercegovački su Hrvati pogodniji za uvođenje nekih rezolutnijih rješenja zato što ih je (nažalost) manje i jer su (politički) kompaktniji od Hrvata u Republici Hrvatskoj. Ono što se uvede u BiH teško će se moći zanemariti u Zagrebu ${ }^{34}$ pa će tako Hrvati iz $\mathrm{BiH}$ postati sukreatori hrvatske jezične politike, a ne samo „poslušnici“ koji osluškuju što će Zagreb reći i učiniti.

\section{Prijedlozi mogućih jezičnih odluka ${ }^{35}$}

Da bi Hrvati iz BiH mogli sukreirati hrvatsku jezičnu politiku, nužno je ponuditi i neka konkretna rješenja, a ne samo nijemo promatrati što se zbiva. Ovdje se, u najkraćim crtama, navode neke mogućnosti koje bi se mogle razmotriti, bez ikakvih pretenzija da su konačne i najbolje.

Polazeći od pretpostavke da nitko ozbiljan više ne će zadirati u dublje pravopisne odluke i da će postojeće pravopisno načelo (fonološki pravopis s morfonološkim primjesama) ostati, mogu se pokušati iznaći rješenja za one nedoumice koje se nalaze u postojećim pravopisima,

\footnotetext{
${ }^{33}$ Ranko Matasović, „O položaju i identitetu hrvatskoga jezika u BiH,“ Vijenac, 654, 28. ožujka (2019): 17.

${ }^{34}$ Slično kao koncem 19. stoljeća, ali ovaj put bi Hrvati sami kreirali svoju sudbinu.

${ }^{35}$ Uvidom na mrežne stranice Filozofskoga fakulteta u Mostaru (https://ff.sum.ba/hr) lako je uočiti da se ovdje doneseni prijedlozi ne podudaraju u potpunosti s tamošnjom jezičnom praksom.
} 
te se razlike mogu lako pobrojati i onda za Hrvate u BiH primijeniti ono što bi se smatralo najboljim. Tako bi bosansko-hercegovački Hrvati mogli utjecati na rješenje nekih jezičnih pitanja koja se već desetljećima predstavljaju kao bauk i nekakav ideološki sukob, oko kojih se lome koplja u samoj Hrvatskoj:

a) ne ću/neću - kada je riječ o pisanju niječnoga oblika pomoćnoga glagola htjeti, ne postoje neki posebni jezični razlozi koji bi prevagnuli bilo na jednu, bilo na drugu stranu, ni jedno rješenje nije „hrvatskije“36 od drugoga pa bi ovo bilo čisto „praktično“ pitanje i stoga se preporučuje pisati odvojeno;

b) greška/grješka - kada je riječ o pisanju je iza pokrivenoga $r$ nema razloga da se inzistira na pisanju s $j$ (osobito kada se osluškuje izgovor Hrvata u $\mathrm{BiH}),{ }^{37}$ iako se ne bi smatralo pogrešnim jer izdanja Filozofskoga fakulteta u Mostaru preferiraju upravo to jekavsko pisanje (npr. časopisi Hum i Hercegovina); ovo je točka koja svakako zaslužuje šire rasprave, a eventualno bi se mogle pobrojati i propisati riječi u kojima bi se pisalo $\mathrm{s} j$ (a onda posljedično i izgovaralo), a da to ne zadire previše u sam izgovor;

c) zadatci/zadaci; uradci/uraci i sl. - kada je riječ o gubljenju $d$ i $t$ ispred $c, \check{c}$ u oblicima imenica s nepostojanim $a$ u završetku -dac, -dak, -tac, -tak, -tka čini se da je, barem kad je riječ o pravopisnim priručnicima $^{38}$, ovo pitanje riješeno i u samoj Hrvatskoj jer dva najrecentnija propisuju pisanje $t$ i $d$.

Kada je riječ o navescima $a, u, e$ u genitivu, dativu i lokativu jednine pridjevno-zamjenične sklonidbe muškoga i srednjega roda, bilo bi dobro odustati od slobodne uporabe i propisati:

\footnotetext{
${ }^{36}$ Pravopisni pododbor godine 1877. propisao je „da se u glagolju negacija piše razstavljeno od glagolja, dakle: ne mogu, ne vidim“, dok Pavić tomu pravilu pridodaje izuzetke pa da se tamo „gdje se je negacija posve stopila sa glagoljem, t. j. u niesam, nemam i neću piše zajedno“ (Ladislav Mrazović, „Ob ustanovi hrvatskoga pravopisa,“Vienac, 14 (1877): 221). Promjena je nastupila od Hrvatskoga prvopisa Ivana Broza (1892) koji je propisao odvojeno pisanje: ne ću, a takvu je praksu zadržao i njegov nasljednik Dragutin Boranić koji u izdanjima svojega pravopisa iz 1947. i 1951. godine propisuje isto odvojeno pisanje (iznimka su izdanja iz 1930. i 1934., tiskana nakon Pravopisnoga uputstva, ali je tu u cijelom pravopisu uvedeno ,jednačenje prema srpskomu“ pa imamo pisanje daću, nosićeš i sl.). Novosadskim dogovorom ponovno se uvodi sastavljeno pisanje neću, nećeš...

${ }^{37}$ Tako je jedan profesor s Filozofskoga fakulteta u Mostaru duhovito primijetio da on piše grješka, a izgovara greška što bi također mogao biti način rješavanja te situacije, svjesni odabir u pisanom tekstu nauštrb vlastitoga izgovora.

${ }^{38}$ Drukčija je situacija s medijima koji se čak i onda kada promoviraju neki pravopis i njegova rješenja, kao npr. Hrvatski pravopis Instituta za hrvatski jezik i jezikoslovlje, ne drže tih rješenja.
} 
a) dosljedno pisanje obveznoga nastavka $-a$ u genitivu (hrvatskoga standardnoga jezika)

b) dosljedno pisanje obveznoga nastavka - $u$ u dativu (hrvatskomu standardnomu jeziku)

c) dosljedno izostavljanje nastavka u lokativu (hrvatskom standardnom jeziku).

Ove bi mogućnosti mogle izazvati dosta polemika, osobito odustajanje od pisanja -e u lokativu, ali takvo je pisanje dosljednije od dosadašnjega u kojem se miješaju pisanja -e i $-u$ u dativu i lokativu, a u skladu je i s hrvatskom dovukovskom tradicijom.

Prijedlog prema bi se moglo jednostrano propisati uz dativ ${ }^{39}$ i tako se vratiti hrvatskoj tradiciji, ali i spriječiti nepotrebna „natezanja“ koji padež dolazi uz njega koja su nastala kada ga se krajem 19. stoljeća htjelo vezati samo uz lokativ, što nije uspjelo u potpunosti zaživjeti o čem svjedoče i suvremene hrvatske gramatike.

U sintaksi bi posebno trebalo pripaziti na rečenične konstrukcije jer je sintaksa najviše na „udaru“ srodnih jezika koji imaju više govornika i jače medijsko zaleđe od Hrvata u BiH. Tu bi se moglo oprimjeriti što je i kako ispravno u standardnom jeziku, a što je prisutno u govorenom jeziku pojedinih Hrvata u BiH.

Neki budući rječnik koji bi prikupio i opisao leksičke osobine bosansko-hercegovačkih Hrvata morao bi sadržavati brojne leksičke posebnosti koje postoje u njihovu jeziku, prije svega orijentalizme. Naravno da to treba dobro odvagnuti i odlučiti što je „nužno“ potrebno, a što nepotrebno i nametnuto tijekom godina tuđih uprava i vlasti.

Književni i razgovorni stilovi hrvatskoga jezika trebaju i moraju zadržati apsolutnu slobodu jezičnoga oblikovanja te se smatraju dijelom hrvatskoga jezika dok god prate i slijede njegove zakonitosti, bez obzira na izražajne mogućnosti koje rabe u danom trenutku. Naposljetku, hrvatske književnike iz $\mathrm{BiH}$ i u $\mathrm{BiH}$ treba promatrati i vrednovati kao dio istoga književnoga korpusa, a ne kao neki pokrajinski odvojak koji se želi prikrpati matici zemlji.

Naravno da ovaj izneseni prijedlog nije ni najbolji ni konačan, on je samo prijedlog i kao takav se može razmatrati, nadopunjavati ili čak u potpunosti odbaciti. Bit će uspješan ako pobudi pojedina pitanja u hrvatskoj jezikoslovnoj zajednici koja su do sada bila izbjegavana. Hrvati podrijetlom iz Bosne i Hercegovine ili oni koji još uvijek žive i rade u BiH (kao i drugi Hrvati drugdje koji se bave jezikoslovljem) moraju

${ }^{39}$ Tako čini Gramatika hrvatskoga jezika Josipa Silića i Ive Pranjkovića, str. 222. 
ravnopravnije i više sudjelovati pri izradi nekih budućih jezikoslovnih priručnika ili smjernica oko budućega razvoja hrvatskoga jezika. Ne smije se odvajati i promatrati hrvatski jezik u BiH kao nešto zasebno u odnosu na hrvatski jezik u samoj Republici Hrvatskoj, jer on to nije. Hrvatski jezikoslovci iz $\mathrm{BiH}$ trebaju se svojim prijedlozima svakako više uključiti u rad institucija koje skrbe o hrvatskom jeziku.

\section{Zaključak}

Hrvatski jezik u Bosni i Hercegovini prošao je težak i trnovit put do potpune slobode uporabe imena i jezičnih obilježja. Ni danas, iako je hrvatski jezik jedan od triju službenih u $\mathrm{BiH}$, situacija nije u potpunosti povoljna jer se, unatoč negativnim povijesnim iskustvima, želi nametnuti ideja o zajedničkom jeziku. Ovaj put riječ je ili o neimenovanom jeziku za cijelu regiju kojemu se u podlozi nalazi ,štokavica kao zajednička dijalekatska osnovica standardnog jezika ${ }^{\text {“40 }}$ ili o pokušaju vraćanja prevaziđenomu bosanskohercegovačkomu standardnojezičnomu izrazu u okvirima BiH. I dok su oko zajedničkoga bosanskoga jezika suglasni hrvatski i srpski jezikoslovci, regionalnim se projektom naizgled ,ne dovodi u pitanje individualno pravo na iskazivanje pripadnosti različitim narodima, regijama ili državama ${ }^{\star 41}$, odnosno sastavljači Deklaracije dobrohotno ostavljaju ,mogućnost svakom korisniku da ga imenuje kako želi‘ ${ }^{‘ 42}$, ali već i sama činjenica da je projekt predstavljen u Sarajevu može pobuditi određenu dozu sumnje kod najmalobrojnijega naroda u BiH. Kad se tomu pridodaju sve češći i sve glasniji zahtjevi bošnjačkih jezikoslovaca da se njihov jezik i u drugim jezicima mora imenovati bosanskim imenom, odnosno kada pojedinci pod tim imenom, osim Bošnjaka uključuju i druge narode u $\mathrm{BiH}$, onda je jasno da se na mala vrata nastoji dokinuti samostalnost ne samo jezikā nego i narodā u BiH. ${ }^{43}$ Nažalost, uz njihove zahtjeve nesvjesno pristaju i pojedini hrvatski intelektualci koji zahtijevaju da se (još uvijek) hrvatski jezik u BiH razvija neovisno o hrvatskom standardu kakav dolazi iz Zagreba. Svakako da dio zahtjeva treba usvojiti, osobito one što se tiču većega sudjelovanja i utjecaja Hrvata iz $\mathrm{BiH}$ na standardizaciju jedinstvenoga hrvatskoga jezika. Tu će i jezikoslovni Zagreb morati postupati mudrije

40 „Deklaracija o zajedničkom jeziku“ (2017).

${ }^{41}$ „Deklaracija o zajedničkom jeziku“ (2017).

42 „Deklaracija o zajedničkom jeziku“ (2017).

${ }^{43}$ Usp. Halilović, „Jezička stvarnost u Bosni i Hercegovini,“ 133. 
i uvažavati neke posebnosti koje još uvijek postoje u govorima bosanskohercegovačkih Hrvata. Bilo bi dobro da ne čekaju da Hrvati „prirodno“ odumru s tih područja kako bi se mogle zanemariti neke činjenice. U radu su predstavljeni mogući putovi i doneseni prijedlozi oko kojih bi hrvatski jezikoslovci podrijetlom iz $\mathrm{BiH}$ ili oni koji žive i rade u $\mathrm{BiH}$ mogli poduzeti i konkretne radnje. Tek tada će se ustvari vidjeti koliko se uvažava i cijeni njihov trud i zalaganje i koliko su „ravnopravni“ dionici iste jezične sudbine. Eventualno neprihvaćanje i najmanje razine prijedloga Hrvata iz $\mathrm{BiH}$ značit će potpuni poraz i u dogledno vrijeme rascjep hrvatskoga jezičnoga jedinstva.

\section{Literatura}

Bloomfield, Leonard. Language. London: George Allen \& Unwin Ltd., 1973.

Bošković, Mirko. Odvojeno mišljenje suca mr Mirka Boškovića u predmetu U-12/97 (1998), pristupljeno 18. rujna 2019, http://www.ustavnisudfbih.ba/hr/ open_page_nw.php?1=hr\&pid=151.

Brozović, Dalibor. „Odnos hrvatskoga i bosanskoga odnosno bošnjačkoga jezika.“ Jezik: časopis za kulturu hrvatskoga književnog jezika, god. 47, br. 1 (1999): $13-16$.

Brozović, Dalibor. „Uloga bosanskohercegovačkih franjevaca u formiranju jezika hrvatske književnosti i kulture - od Divkovića do fra Grge Martića.“ Jezik: časopis za kulturu hrvatskoga književnog jezika, god. 20, br. 2 (1972): 37-51.

Čedić, Ibrahim. „Bosanskohercegovački standardnojezički izraz - bosanski jezik.“ U Bošnjački pogledi na odnose između bosanskog, hrvatskog i srpskog jezika, ur. B. Tošović i A. Wonisch, 41 - 50. Graz - Sarajevo: Institut für Slawistik der Karl-Franzens-Universität Graz - Institut za jezik, 2009.

Deklaracija o zajedničkom jeziku (2017), PEN Centar BiH iz Sarajeva, Udruženje Krokodil iz Beograda, Centar za građansko obrazovanje (CGO) iz Podgorice, Udruga Kurs iz Splita, pristupljeno 10. siječnja 2020., http://jezicinacionalizmi.com/deklaracija/.

Dodig, Radoslav. „Bošnjački ili bosanski.“ Dani, 132 (1999), pristupljeno 29. srpnja 2020., http://hamdijadobruna.com/fstab/jezik6.html\#b1.

Gavran, Ignacije. „Uvod.“ U Nikola Lašvanin. Ljetopis, ur. Ignacije Gavran, 5-32. Sarajevo - Zagreb: Synopsis, 2003.

Halilović, Senahid. „Jezička stvarnost u Bosni i Hercegovini.“ Socjolingwistyka, XXVIII (2014): 121-135.

Ivšić, Stjepan. „Etimologija i fonetika u našem pravopisu.“ Hrvatski jezik, god. 1, br. 1 (1938): 3-13.

Karadža, Mevlida. „Sociolingvistički aspekti jezičke situacije u Bosni i Hercegovini.“ U Bošnjački pogledi na odnose između bosanskog, hrvatskog i srpskog jezika, ur. B. Tošović i A. Wonisch, 67-76. Graz - Sarajevo: Institut für Slawistik der Karl-Franzens-Universität Graz - Institut za jezik, 2009. 
Lovrenović, Ivan. Promemorija o (hrvatskoj) jezičnoj politici u Bosni i Hercegovini (2012), pristupljeno 5. travnja 2019., https://www.6yka.com/novosti/ promemorija-o-hrvatskoj-jezicnoj-politici-u-bosni-i-hercegovini.

Maretić, Tomo. „Jedna značajna četrdesetogodišnjica - Kako je došlo do uvođenja fonetskog pravopisa u Hrvatskoj i Slavoniji 1892.“ Pravda, god. XXVIII, br. 6-9 (1932): 19.

Matasović, Ranko. „O položaju i identitetu hrvatskoga jezika u BiH.“ Vijenac, 654, 28. ožujka (2019): 16-17.

Mlakić, Josip. „Hrvatski jezik je vlasništvo i nas Hrvata u BiH.“ Vijenac, 373, 19. lipnja (2008), razgovor vodila Laura Mihaljević, pristupljeno 27. siječnja 2020., http://www.matica.hr/vijenac/373/hrvatski-jezik-je-vlasnistvo-i-nashrvata-u-bih-22218/.

Mrazović, Ladislav. „Ob ustanovi hrvatskoga pravopisa.“ Vienac, 14 (1877): 217-221.

Musa, Marija. Hrvatski jezik u Bosni i Hercegovini u javnoj komunikaciji od 1945. do danas. Mostar: Školska naklada, 2018.

Palić, Ismail. „Mogućnosti funkcioniranja triju standardnih jezika (bosanskoga, hrvatskoga i srpskoga) u Bosni i Hercegovini.“ U Bošnjački pogledi na odnose između bosanskog, hrvatskog i srpskog jezika, ur. B. Tošović i A. Wonisch, 77-90. Graz - Sarajevo: Institut für Slawistik der Karl-Franzens-Universität Graz - Institut za jezik, 2009.

Papić, Mitar. Školstvo u Bosni i Hercegovini za vrijeme austro-ugarske okupacije (1878 - 1918). Sarajevo: Veselin Masleša, 1972.

Pranjković, Ivo. Franjevačko spisateljstvo na hrvatskome jeziku. Zagreb: Hrvatska sveučilišna naklada, 2008.

Presuda Ustavnoga suda Federacije BiH, broj U-7/98, 1998., pristupljeno 22. lipnja 2019., http://www.ustavnisudfbih.ba/bs/open_page_nw.php?l=bs\&pid=178.

Radić, Antun. „Hrvatski književni jezik.“ Glas Matice Hrvatske, god. II, br. 1-2 (1907): 2-4.

Saussure, Ferdinand de. Tečaj opće lingvistike. Zagreb: ArTresor naklada - Institut za hrvatski jezik i jezikoslovlje, 2000.

Silić, Josip, i Ivo Pranjković. Gramatika hrvatskoga jezika. Zagreb: Školska knjiga, 2005.

Ustav Federacije Bosne i Hercegovine s amandmanima XXVII-LIV (Wolfgang Petrisch) od 28. 4. 2002., pristupljeno 31. srpnja 2020., http://predstavnickidom-pfbih.gov.ba/upload/file/ustav/ustav_precisceni_tekst.pdf.

Ustav Federacije Bosne i Hercegovine, 1994, pristupljeno 31. srpnja 2020., http:// www.fbihvlada.gov.ba/hrvatski/federacija/ustav_hr_stari.htm.

\section{The Croatian Language in Bosnia and Herzegovina - Life on the Edge (Existence and Perspectives)}

Summary: The paper will consider the position of the Croatian language in Bosnia and Herzegovina and attempt to answer the question whether Croats living in Bosnia and Herzegovina should be using Standard Croatian as prescribed by the 
authorities in Zagreb or if they should insist upon their own peculiarities resulting from specific social and political circumstances as well as a hundred years of separation from the homeland. What position should be taken with regards to numerous words of Turkish, Arabic and Persian origin making up the vocabulary of Croats living in Bosnia and Herzegovina, considering the wide variety of words of German, Italian and Hungarian origin characteristic of the language spoken in different parts of Croatia? There are those who believe that the Croatian language in Bosnia and Herzegovina should and must be separate in some of its language solutions from the Croatian language as standardised by the authorities in Zagreb. They subscribe to the view that the Croatian language in Bosnia and Herzegovina, as well as the Croats themselves, are systematically neglected by the homeland, being used only for political point-scoring. On the other hand, the University of Mostar is the only university in Bosnia and Herzegovina teaching in the Croatian language as prescribed by the authorities in Croatia, invoking the unity of the Croatian people and language used by all Croats, regardless of their country of residence. The paper will try and clarify which position is the correct one, whether there can be only one correct position or the solution for Croats in Bosnia and Herzegovina lies in a different direction.

Keywords: Croatian language, Bosnia and Herzegovina, standardisation, perifery, existence, perspective 